\title{
State officials and illicit asset-grabbing: The Roman approach
}

\author{
A. Apsitis and J. Joksts \\ Rīga Stradiņš University, Riga, Latvia
}

\begin{abstract}
The article reflects author's findings regarding the regulation found in Roman legal sources, which is directed against corruptive activities of persons in public state positions, in particular in relation to unlawful seizure of assets belonging to citizens. Legal mechanisms are examined in relation to cases of force (vis-Latin) and fear (metus-Latin) application. The Code of Justinian (Codex Iustinianus) and The Digest (Digesta) contained regulation in relation to interpretation and application of The Julian Law on Extortion (Lex Iulia repetundarum, 59 B.C.) in cases of all types of extortion and bribery with the involvement of public office administering persons, including judges and arbitrators, are examined.

Key words: Roman law; Ancient Rome; asset-grabbing
\end{abstract}

\section{Introduction}

Possible corruption of persons in public state positions is a serious threat to sustainable development and efficient functioning of the state. This particularly holds true for corrupting activities of the officials and/or persons belonging to the judicial system in relation to unlawful seizure of assets belonging to the state citizens.

Particular hazards for sustainable development of the state are caused by unlawful seizure of material benefit creator-entrepreneur assets. Functioning of entrepreneurial environment in accordance with the principles of lawfulness is regarded as an essential prerequisite for sustainable development. State power, inter alia, must be able to ensure that valuables owned by an entrepreneur or those under any law-ful control are adequately protected against any threats and unlawful claims, as well as guarantee inviolability of an entrepreneur's life and health protecting him against any unlawful acts [1].

The key ingredient of success factors for sustainable entrepreneurship is motivation of entrepreneur that could be increased by various political measures aiming to rise initiative of people to run existing or start new business ventures in secure and sustainable way [2].

Namely, the basis of sustainable development of any country is formed by, inter alia, a stable, efficient and fair system of state administration and judiciary which counterbalances the interests of the whole society and its individual elements.

The origins of legal framework for such kind of system, just like of many other contemporary legal thought phenomena, go back to Roman law - as it is known, within the ancient Roman civilization a rather complex and very successful legal basis was set up, so the large and for that time highly developed empire could successfully function. Also, it is necessary to point out that legal principles created by Romans, in particular in areas of 
private or civil rights have proven to be so successful that they still are the basis of private law of the West and the whole globalized world [3].

Therefore, understanding of the mentioned legal concept is impossible without a thorough study of the primary sources of Roman law. The aim - to facilitate in-depth knowledge of contemporary legal norm makers, enforcers and implementers about the legal framework for stable, efficient and fair system of state administration and judiciary by studying information found in the primary sources of Roman law.

\section{Materials and methods}

Within the research there were performed the studies and analysis of the primary sources of Roman Private Law (The Digest (Digesta) (Krueger; Mommsen 1928) [4] and The Code of Justinian (Codex Iustinianus) (Krueger 1906) [5]), mostly by applying the inductive, deductive and comparative methods.

\section{Results and discussion}

The sources of Roman law recognise and define the rights of the Roman magistrates (elected officials) to duly use powers or force in compliance with the law and legal powers of their position (D 4.2.3.1).

However, if a magistrate of the Roman people or governor of a province (populi Romani magistratus vel provinciae praeses - Latin) committed a wrongful act, for instance, extorted money by threatening with death or whipping (mortis aut verberum terrore pecuniam alicui extorserit - Latin), the mechanisms provided for in the laws for the cases of force and fear were applicable against them (D 4.2.3.1).

Equally, if someone who, due to the pressure on the part of the administrative officers, i.e. through the intervention of the governor's attendants (the apparatus) (apparitione praesidis interveniente - Latin), without the judge's knowledge (sine notione iudicis Latin), was compelled to pay (coactus est dare - Latin) a non-existing debt which he was coerced to undertake by force (per vim - Latin), he could claim the judge's (iudex - Latin) decision on restitution ${ }^{\mathrm{a}}$ of what was illegally extorted (inciviliter extorta restitui - Latin)

\footnotetext{
${ }^{a}$ What is done through fear can never be ratified or confirmed (ratum habebit - Latin) on the part of a state official (D 4.2.21.1, D 4.2.1). The victim, i.e. someone who was compelled to act against his will, could restore his earlier status through restitution (D 4.2 .3 pr.). Respectively, full restoration (restitutio - Latin) of the initial situation based on the authority of the court that, depending on a specific case (see D 4.2.7.1, D 4.2.8 pr., D 4.2.9.2, D 4.2.9.3, D 4.2.9.4, D 4.2.9.7, D 4.2.9.8, D 4.2.10, D 4.2.11, D 4.2.14.6, D 4.2.14.8, D 4.2.22, D 4.2.23.1, D 4.2.23.3), could be manifested, for instance, as a return of a thing when said thing was given to someone under duress together with an obligation to reimburse the victim for deceit (dolo - Latin) (D 4.2.9.7, D 4.2.9.5). If the defendant did not apply for voluntary restoration (restitution) of the initial situation and intervention of court was necessary, the victim was authorised to claim a fourfold repayment of the losses incurred by him, i.e. four times more than what would be voluntarily recovered (restituted) (D 4.2.14.1, D 4.2.14.3, $\mathrm{D} 4$ 4.2.9.7, D 4.2.9.6). (After a year, the victim only had the right to claim repayment of the simple value (simplum actionem - Latin), not always, but only on cause being shown - the process was connected with investigation of the case (sed causa cognita - Latin) (D 4.2.14.1)). Fourfold payment included the restitutable value itself; therefore, the restitutable amount to which a penalty of threefold the amount was added was actually supposed to be paid (D 4.2.14.10, D 4.2.14.9). To calculate the fourfold payment, the restitutable value itself was taken into consideration together with all fruits (cum fructibus et omni causa - Latin) (D 4.2.14.7). Determining the amount of payment, only the loss actually incurred by the victim was valuated (D 4.2.21.2). It is specified that the fourfold payment
} 
(D 4.2.23.3). Debts could only be enforced in compliance with the respective procedural order (D 4.2.13); therefore, non-procedural intervention on the part of state management attendants was regarded as a wrongful act: 'But if he satisfies a debt by [getting] a simple order (Quod si debitis satisfecit simplici iussione - Latin) rather than [through] a court investigation (et non cognitione habita - Latin), even though recovery under extraordinary proceedings has not been performed (quamvis non extra ordinem exactionem fieri - Latin), but [an order] has been civilly executed (sed civiliter oportuit - Latin); however, settling debts [in such a manner]... (tamen quae solutioni debitarum... - Latin) [their] recovery is unlawful (revocare incivile est - Latin)' (D 4.2.23.3).

Invalidity of transactions made as a result of thrusting someone into prison with the aim to extort something from him ('...to extort something (...ut aliquid ei extorqueret - Latin)') were pointed out (D 4.2.22), as well as the officials' duty to ensure (' $\ldots$ the governor of the province will restore the matter to its rightful position (...res suae aequitati per praesidem provinciae restituitur - Latin)') that the sold property of the person threatened with court investigation will be restituted (D 4.2.23.1).

Simultaneously, obviously with the purpose to reinforce the authority of the state power, it was actually acknowledged that unlike people not holding any office, the officials and administrative officers had greater possibilities to protect themselves from force and fear should an attempt to employ them be made: 'It is impossible that a person who alleged that he held rank (qui claram dignitatem se habere praetendebat - Latin) ${ }^{\mathrm{b}}$ was compelled in the city groundlessly to pay a non-existing debt (Non est verisimile compulsum in urbe inique indebitum solvisse eum - Latin). [Since] he could have referred to the public law ${ }^{\mathrm{c}}$ (cum potuerit ius publicum invocare - Latin) and turn to someone having authority (power) (et adire aliquem potestate praeditum - Latin) who could prohibit subjecting him to force (qui utique vim eum pati prohibuisset - Latin). But presumption of this kind can be rebutted [only with] the most manifest proof of violence (sed huiusmodi praesumptioni debet apertissimas probationes violentiae opponere - Latin)' (D 4.2.23 pr.).

It should be noted that the Roman law contained provisions which are rather directly against alleged corrupt activities from persons in public state positions. In this context Lex Iulia repetundarum (59 B.C.) - last and severest law of Roman republic regarding extortion (repetundae - Latin) should be mentioned. The law was adopted by the proposal legislative initiative of Julius Caesar (C. Iulius Caesar, 100 B.C. - 44 B.C.) in meeting the obligations of consul. It was still in force in accordance with Roman law codification realized by the Emperor Justinian (Flavius Petrus Sabbatius Iustinianus Augustus, c. 482 $\mathrm{AD}-565 \mathrm{AD}$ ) in the period from 529 A.D. to 534 A.D. (see D 48.11; C 9.27) and covered all types of bribery cases involving public office administering persons, including judges and arbitrators [6].

Responsibility was requested from the person who, guided by corrupt considerations, had done more or less (magis aut minus - Latin), than his official duties requires. (D 48.11.4)

should be regarded only as interest due to the litigant (interest quadruplari solum - Latin) (D 4.2.14.14) [1].

b Respectively, alleged with reference to his high office or administrative officer's position; to read more about administrative officer hierarchy - ordo dignitatum (Latin), please see C 12.1 tit.; C 12.8 tit.; C 1.52 tit.

${ }^{\mathrm{c}}$ Respectively, to refer to Ius publicum (Latin), i.e. legal norms in relation to existence, organisation and functioning of a state - the norms "which cannot be changed by the contracts signed between private individuals"; please see D 2.14.38; D 50.17.45.1, see also: A. Berger,. Encyclopedic Dictionary of Roman Law. 532 (The American Philosophical Society, Philadelphia, 1953, 1991) [6]. 
In addition, charges of public crimes (crimen publicum - Latin) could have put not only to the recipient of the bribe, but also the giver. (non modo adversus accipientem, sed etiam adversus dantem - Latin). (C 9.27.6.1)

The Julian Law on Extortion (Lex Iulia repetundarum - Latin) was applied to the money received by someone who took the magistrates office (magistratu - Latin), was endowed with power (potestate - Latin), carried out administrative duties (curatione Latin), was appointed legate (legatione - Latin) or executed any other official work or public profession. The law was also applicable to the associates (cohorte - Latin) of the mentioned above. (D $48.11 .1 \mathrm{pr}$.)

For example, sources speak of a provincial administrator (the head of a military district) - Duke (Dux - Latin) who was caught in corruption, "who acted badly" (ducem qui male egit - Latin) - from "our residents of the province" (provincialibus nostris - Latin), "extorted or took away" (rapuit aut sustulit - Latin) (C 9.27.1), the superintendent of imperial buildings (comite domorum - Latin), who could have extorted money from his inferior subordinate officials - e.g. from procurator (procurator - Latin, official of the administration), from chief of subaltern officers in imperial female apartments/imperial garment factory (praepositus gynaecei - Latin, see C 11.8), from tabularius (tabularius Latin, a subordinate official in the fiscal administration, clerk, tax accountant, archivist, see C 10.71), from collector of taxes (susceptor - Latin, see C 10.72; C 11.70), from the colon (colonus - Latin) or any other (C 9.27.5 pr.), city magistrates (urbani magistratus - Latin), who must refrain from any tarnishment of reputation (ob omni sorde se abstineant - Latin) and who, during one year (in anno - Latin), can't receive more gifts and bounty than in value of one hundred gold coins (aureorum centum - Latin) (D 48.11.6.2) etc.

According to the Julian Law on Extortion, nobody with corresponding powers was allowed to accept money for the purpose of recruiting or releasing soldiers from the service, and nobody was allowed to take money for giving opinion in Senate or the public council. (D 48.11.6.2)

Responsibility for the crime of extortion was requested (crimine repetundarum postulantur - Latin) from the person who, hoping to receive money, withdrew from public duty (office) execution. (D 48.11.9)

It was possible to hold persons in occupying positions responsible for corrupt practices committed by their subordinates - such as already mentioned Duke (Dux - Latin) was responsible for anything which the members of his household (domesticus - Latin), his soldiers (manipularius - Latin), and servants (minister - Latin) illegally received.(C 9.27.1)

Furthermore - subordinates also were materially responsible for the extortion of their superiors, unless they had reported such fact in accordance with the prescribed deadlines. (C 9.27.5.1)

According to the Julian Law on Extortion, claim rights (actio - Latin) against the heirs (heredes - Latin) of officer/official caught in corruption were given, but only within a year after (intra annum dumtaxat - Latin) the death of the accused (a morte eius qui arguebatur - Latin). (D 48.11.2)

The law foresaw exceptions to those, from whom receiving money was allowed: cousins (sobrinis - Latin), the nearest blood relatives (propioreve gradu cognatis - Latin) and wives (uxore - Latin). (D 48.11.1.1)

Also, sources indicated that the Julian Law on Extortion included exhaustive list in accordance with the persons responsible - those who were excluded from the law, were allowed to receive money without restriction, but those listed therein were not permitted to catch (capere - Latin) anything from anyone. (D 48.11.7.1)

From the officers/officials, at least in theory, impeccable reputation and excellent moral and ethical qualities were requested - “... let those men (viros - Latin) of the provincial management get power, who honour the brilliant, not ambitions or search for goods 
([viros]...qui honoris insignia non ambitione vel pretio - Latin), but fair / honest life ... let them serve as evidence of elevation ... (sed probatae vitae et ... testimonio promoveri Latin)" (C 9.27.6 pr.).

Similarly, parties to the legal proceedings had to behave with dignity and honor - "All representatives of the parties (cognitores - Latin) and the judges (iudices - Latin) from the [litigants] money (pecuniis - Latin) and property (patrimoniis - Latin) hold further [their] hands (manus abstineant - Latin) nor consider others quarrels as [a source of] their prey (neque alienum iurgium putent suam praedam - Latin)." (C 9.27.3)

Thus, according to the Julian Law on Extortion, it was due to hunt down the one who, being endowed with some sort of power (qui, cum aliquam potestatem haberet - Latin), received money for the judgment or decision making or not making. (D 48.11.3)

The law stated, that no one should have received anything for making of judge's judgment or arbitrator's decision, nor for changing of sentence, nor for not making judgment, nor for not changing of sentence, nor for not giving the order, nor for enclosure of human (hominem - Latin) in public prison, nor for binding with obligations, nor for ordering to put into chains, nor for ordering to free from chains, nor for conviction or justification of human (hominem condemnandum absolvendumve - Latin), nor for assessment of imposed amount, nor for sentencing or not sentencing death or money penalty. (D 48.11 .7 pr.). Nobody with the corresponding powers was allowed to accept money for someone's prosecution or not prosecution (accusandum vel non accusandum Latin). (D 48.11.6.2)

According to the Julian Law on Extortion, judge's assistants (comites - Latin) also could be persecuted. (D 48.11.5.)

Convicted, according to the Julian Law on Extortion, was forbidden (prohibetur Latin) to be a judge (iudex - Latin), case initiator, someone's representative in court or testify publicly (testimonium publice dicere - Latin). (D 48.11.6.1)

Thus, witnesses involved in the proceedings were also responsible - "[In accordance] with the same law accountable (Eadem lege tenentur - Latin) are those, who receive money (pecuniam acceperint - Latin) for referring or not referring the testimony (denuntiandum vel non denuntiandum testimonium - Latin).” (D 48.11.6 pr.)

Similar to the situation with the officers/officials, in accordance with the Julian Law on Extortion, responsibility was required from the successors of the judges caught in corruption - "We let the judges know, that penalties imposed for their caused damage can be collected not only from themselves, but also their heirs (Sciant iudices super admissis propriis aut a se aut ab heredibus suis poenam esse repetendam - Latin).” (C 9.27.2)

The law foresaw reporting obligation of officials and citizens on noticed lawlessness in judges actions - if any occupying honorary position (honoratorum - Latin), decurion (decurionum - Latin), possessor of property (possessorum - Latin), and finally even colon (colonorum - Latin) or anyone occupying ordinary position (ordinis - Latin) was intimidated or shaken (concussus - Latin) from the judge, or if he became aware that the judgment of the court is sold, or of he knew that the penalty was dismissed/ revised for a fee (poenam vel pretio remissam - Latin), in immoral greed hoping for a reward, or if he later could confirm judge dishonesty at some time in past cases, he, either during administration or after administration (vel administrante eo vel post administrationem Latin), had to notify about the crime submitting evidence. If the accusation was confirmed, the reporter was honoured and glorified (et victoriam reportaturus et gloriam - Latin). (C 9.27.4)

In addition to the rules, which were directed against the corrupt activities from the persons who occupied public state positions, the Julian Law on Extortion contained a rather strict requirements regarding public procurement and orders for the needs of state or municipality - it was determined that no enforceable public work (opus publicum - Latin) 
is not acceptable as finished, grain crops or food (frumentum - Latin) for public distribution is not considered delivered or procured, buildings are not considered renewed, before mentioned public projects are not completed, delivered, accepted according to the law. (D 48.11.7.2)

Internal aversion of position occupants to corruption as a phenomenon was attempted to cultivate with sacramental activities - mandatory assistance oath: "... so that those who are honoured with the post...giving the oath [could] declare, that for entrusted administration they have not given, or will not give later, themselves or through intermediaries (sive per se sive per interpositam - Latin), in violation of the laws or personal oath, or [by conclusion of] donation's, sale's title, or any other basis contract, and therefore, with the exception of salary and absolutely nothing [else] being in administration, also after the administration (post depositum officium - Latin) ... will not be accepted." (C 9.27.6 pr.)

As it is known, fear from the anger of Supremacy can serve as a fairly strong incentive element - “...nobody in fear of God [anger] will not flout the oath, thus forgetting about his own soul salvation, preferring any profiting... (...neminem divini timoris contemnendo iureiurando arbitramur immemorem, ut saluti propriae ullum commodum anteponat... Latin)". (C 9.27.6.1 $)^{\mathrm{d}}$

It must be noted, that Roman legislators were perfectly aware of the importance and need of secular incentive measure, thus laying down a very effective sanctions mechanism against persons who were possibly involved in corrupt activity - “...however, to fear about the salvation of the soul danger [of punishment] needs to be added so, if anyone dared to behave recklessly against given sacrament/oath (sacramenta neglegere - Latin), four time penalty (quadrupli poena - Latin) to the one who is convicted must be achieved by all means." (C 9.27.6.1). Thus the offender was due quadruple punishment of the received or given bribe value.

It was directly stated on the general preventive aim of the penalty - with a certain type of intimidation measures to ensure compliance with the law and to discourage public office holder / person executing duties from committing criminal offence - "May the punishment (poena - Latin) for one be an example for a lot, we determine that the Duke, who acted badly (ducem qui male egit - Latin), must be arrested and sent to his subordinate province, where what his household members (domesticus - Latin), soldiers (manipularius - Latin) and servants (minister - Latin) have received, and he himself, has extorted or taken away (rapuit aut sustulit - Latin), is forced to pay in quadruple" (C 9.27.1)

In addition, according to the law on extortion (ex lege repetundarum - Latin), regarding those responsible acted in accordance with extraordinary proceedings (extra ordinem -

\footnotetext{
${ }^{d}$ It is necessary to mention, that during times of Justinian, Christianity took over the Roman empire, according to it's religiously ethical principles, as it's known, manifestations of bribery and corruption is condemned, especially according to decision of the court: "nec accipias munera quae excaecant etiam prudentes et subvertunt verba iustorum" - Latin [7] ("And thou shalt take no gift: for the gift blindeth the wise, and perverteth the words of the righteous." [8]/ "You shall take no bribe, for a bribe blinds those who have sight and perverts the words of the righteous." [9]) (Exodus 23:8); "nec in alteram partem declinent non accipies personam nec munera quia munera excaecant oculos sapientium et mutant verba iustorum" - Latin [7] ("Thou shalt not wrest judgment; thou shalt not respect persons, neither take a gift: for a gift doth blind the eyes of the wise, and pervert the words of the righteous." [8]/ "You shall not pervert justice. You shall not show partiality. You shall not take a bribe, for a bribe blinds the eyes of the wise and perverts the words of the righteous." [9]) (Deuteronomy 16:19); "maledictus qui accipit munera ut percutiat animam sanguinis innocentis et dicet omnis populus amen" - Latin [7] ("Cursed be he that taketh reward to slay an innocent person. And all the people shall say, Amen." [8]/ "Cursed is he who takes a bribe to kill an innocent person. All the people shall say, Amen.” [9]) (Deuteronomy 27:25).
} 
Latin) and often punished with either exile (vel exilio puniuntur - Latin), or even more severe (vel etiam durius - Latin), according to the assessment of the committed offense.

If the guilty had received money for killing people (hominem necandum pecuniam acceperint - Latin), or, even if they had not received money, however, in anger had killed either innocent or one who was not to be punished (vel innocentem vel quem punire non debuerant - Latin), they were "... Punished with death (Capite plecti debent - Latin) or at least sent to the island (vel certe in insulam deportari - Latin) as most of them have been punished (ut plerique puniti sunt - Latin)". (D 48.11.7.3)

As previously mentioned, if someone was convicted according to the Julian Law on Extortion, he was forbidden (prohibetur - Latin) to be a judge (iudex - Latin), the initiator of a case, representative in the court or to publicly testify (testimonium publice dicere Latin). (D 48.11.6.1)

The Julian Law on Extortion foresaw specific consistency in the field of private law circulation - the law stipulated that the sale or lease contract (venditiones locationes Latin), which, due to the pressure of those occupying positions, has been concluded for a higher or lower price than that which would have been fair, becomes invalid (irritas facit Latin) and acquisition on the basis of prescription (usucapionem - Latin) is prevented, before things have not arrived back at it, from which they have departed, or to his heir. (D 48.11.8.1) Similarly: "What, contrary to the law on extortion, has been donated to proconsul or praetor, (Quod contra legem repetundarum proconsuli vel praetori donatum est - Latin) is not obtainable on the basis of prescription (non poterit usu capi - Latin)." (D 48.11.8.pr.)

Anti-corruption obligations provided in the law tied the office holders also after they had passed their office powers - ceased to hold office: “... So they... [could] declare... that ... being in administration and after passing the office (post depositum officium - Latin) they will not accept absolutely nothing [other] than wages." (C 9.27.6 pr.)

Similarly worked reporting obligations of the officials on noticed lawlessness in actions of judges: "... [We demand that he] must report about the crime either during his administration or after the administration time (vel administrante eo vel post administrationem - Latin)." (C 9.27.4)

Also, the responsibility in relation to the Julian Law on Extortion rule violation could be required from officers/officials who had already left the office: “...When he, who accepted the money, has left [his] administrative duties (administratione decesserit - Latin)..."(C 9.27.5 pr.)

The Julian Law on Extortion contained certain prescription periods. Claims (actio Latin) against the heirs (heredes - Latin) of the accused were exercisable only within a year (intra annum dumtaxat - Latin) after the death of the accused (a morte eius qui arguebatur - Latin). (D 48.11.2) Claim rights against the officer/official expired during one year after leaving the post (C 9.27.5 pr.) - if his former subordinates - colleagues had not reported the lawlessness of the former chief in a timely manner, they themselves became materially responsible: "If, however, from the moment when [he] has left the administrative powers, [claim lifting] allotted time has [already] passed, no voice in defence [can't] appear (nulla vox advocationis emergat - Latin), but those procurators (procuratores - Latin), chiefs (praepositos - Latin), colons (colonos - Latin), tabulariuses (tabularius - Latin), tax collectors (susceptores - Latin) are [themselves] responsible for the payment, which they want to challenge." (C 9.27.5.1)

\section{Conclusions}

In the sources of Roman law a significant role is played by the legal regulation intended to combat malice on the part of state officials, administrative officers and judges. 
The sources recognise and define the rights of the Roman magistrates (elected officials) to duly use powers or force in compliance with the law and legal powers of their position (D 4.2.3.1). However, if a magistrate, administrative officer or any other official committed a wrongful act, for instance, extorted money (D 4.2.3.1), compelled somebody to pay a non-existing debt (D 4.2.23.3) or extort something else from him (D 4.2.22), the mechanisms provided for in the laws for the cases of force and fear were applicable against them (D 4.2.3.1).

The victim, i.e. someone who was compelled to act against his will, could restore his earlier status through restitution (D 4.2.3 pr.; D 4.2.23.1 etc.).

Simultaneously, it was actually acknowledged that unlike people not holding any office, the officials and administrative officers had greater possibilities to protect themselves from force and fear should an attempt to employ them be made (D 4.2.23 pr.).

The law of Ancient Rome contained provisions which are rather directly against alleged corrupt activities from persons in public state positions. In this context law relating to extortion (repetundae - Latin) should be mentioned - The Julian Law on Extortion (Lex Iulia repetundarum, 59 B.C.). The law was adopted by the legislative initiative of Julius Caesar in meeting the obligations of consul. It was still in force in accordance with Roman law codification realized by the Emperor Justinian (see D 48.11; C 9.27) and covered all types of bribery cases involving public office administering persons, including judges and arbitrators.

Responsibility was requested from those who guided by corrupt considerations had done more or less (magis aut minus - Latin) than their official duties required (D 48.11.4.), it was possible to prosecute not only the recipient of the bribe, but also the giver of the bribe (C 9.27.6.1). Persons in occupying positions also could be held responsible for their subordinate corruptive activities (C 9.27.1), subordinates were responsible materially for their superiors once extorted, unless such fact was reported (C 9.27.5.1). Claim rights were given against caught corrupt officer's/official's heirs. (D 48.11.2) The law foresaw exceptions to those from whom it was allowed to receive money (D 48.11.1.1), also sources indicated, that the Julian Law on Extortion according to it includes exhaustive list of the persons responsible (D 48.11.7.1). Excellent reputation and excellent moral and ethical qualities were required from officers/officials. (C 9.27.6 pr.)

Similarly, the trial participants - judges, representatives of the parties, etc. had to behave with dignity and honour (C 9.27.3). Thus, under the Julian Law on Extortion, those, who received illegal payments for performed or not performed activities of judicial proceedings, were persecuted (48.11.3; D 48.11 .7 pr., D 48.11.6.2). Judge's assistants could be persecuted for corruptive activities (D 48.11.5.), witnesses (D 48.11.6 pr.), involved in the proceedings were responsible and responsibility was demanded also from the heirs of the judges caught in corruption. (C 9.27.2) The law foresaw official and citizen reporting obligation on noticed lawlessness in judge's activities. (C 9.27.4)

The Julian Law on Extortion contained rather strict requirements regarding public procurement and orders for the needs of state or municipality. (D 48.11.7.2)

Internal aversion of position occupants to corruption as a phenomenon was attempted to cultivate with sacramental activities - mandatory assistance oath, thus emphasizing the motivational impact of fear from God's wrath. (C 9.27.6 pr.; C 9.27.6.1)

At the same time Roman legislators were perfectly aware of the importance and need of secular incentive measure, thus laying down a very effective sanctions mechanism against persons who were possibly involved in corrupt activity - the offender was due quadruple punishment of the received or given bribe value (C 9.27.6.1; C 9.27.1), often they were punished with either exile, or even more severe, according to the assessment of the committed offense - especially if offenders had received money for killing people, then death penalty was possible (D 48.11.7.3). The general preventive aim of the penalty was 
not forgotten - to ensure law enforcement and discourage public office / executing the obligations of persons from a criminal offense (C 9.27.1). According to the Julian Law on Extortion convict was forbidden to be a judge, representative in the court or to publicly testify. (D 48.11.6.1)

The Julian Law on Extortion foresaw specific consistency in the field of private law circulation - the law stipulated that the sale or lease contract, which has been concluded due to the pressure of those occupying positions, becomes invalid (D 48.11.8.1) and acquisition on the basis of prescription is prevented (D 48.11.8.1; D 48.11.8.pr.).

Anti-corruption obligations provided in the law tied the office holders also after they had passed their office powers - ceased to hold office. (C 9.27.6 pr.; C 9.27.4; C 9.27.5 pr.)

The Julian Law on Extortion contained certain prescription periods (they expired within 1 year). (D 48.11.2; C 9.27.5 pr.; C 9.27.5.1).

\section{References}

1. A. Apsīis, J. Joksts, J. Antanavičienè, J. of Sec. and Sust. Iss., Threats to sustainable development: asset grabbing phenomenon and the legal concept of Force and Fear in Roman Law. 6(2), 289, 290, 293, 294 (2016)

ht tp://dx.doi .org/10.9770/jssi.2016.6.2(8)

2. J. Raudeliūniene, M. Tvaronavičienè, I. Dzemyda, (2014) J. of Sec. and Sust. Iss., Towards economic security and sustainability: key success factors of sustainable entrepreneurship in conditions of global economy. 3(4), 77 http://dx.doi.org/10.9770/jssi.2014.3.4 (7)

3. A. Apsītis, Socrates RSU JF el. jur. zin. r. žur., Romiešu sabiedrības (societa) līgums un romiešu tiesiskie principi mūsdienu Latvijas tiesībās [Roman Partnership Agreement (Societa) and Roman Legal Principles in the Law of Modern Latvia] 3(3), 92 (2015)

http://www. rsu. lv/images/stories/dokumenti/publikacijas/ socrates_3_2015.pdf

4. P. Krueger, T. Mommsen, eds., Corpus Iuris Civilis. Digesta. [Body of Civil Law. Digest.] 60, 80-82, 857, 921 (Weidmannos, Berlin, 1928)

http://fama2.us.es/fde/ocr/2006/corpusIurisCivilist1Inst itutionesDigesta.pdf, pp. 143, 163-165, 940, 1004

5. P. Krueger, ed., Corpus Iuris Civilis. Codex Iustinianus. [Body of Civil Law. The Code of Justinian.] 89, 384-385, 453-454, 456 (Weidmannos, Berlin, 1906) http://fama2.us.es/fde/ocr/2007/CorpusIurisCivilisCodexI ustinianus . pd f, pp. 119, 414-415, 483-484, 486

6. A. Berger, Encyclopedic Dictionary of Roman Law. 532, 555 (The American Philosophical Society, Philadelphia, 1953, 1991)

7. Biblia Sacra Vulgata. http://vulgate.org/ot/exodus_23.htm, http://vulgate.org/ot/deuteronomy_16.htm , http://vulgate.org/ot/deuteronomy_27.htm, http://vulgate.org/

8. The King James Bible. http://Ww gutenberg org/files/10/ 10-h/10-h.htm\#The_Second_Book_of_Moses_Called_Exodus. http://WwW gutenberg org/files/10/10-h/ 10-h.htm\#The_Fifth_Book_of_Moses_Called_Deuteronomy, http://WwW gutenberg.org/files/10/10-h/10h.htm\#The_Fifth_Book_of_Moses_Called_Deuteronomy 
(The Project Gutenberg EBook, 2011)

http: / Www gutenberg. org/files/10/10-h/10-h. htm

9. World English Bible with Deuterocanon.

http://ebible org/web/EXO23.htm,

http://ebible.org/web/DEU16.htm.

http://ebible, org/web/DEU27.htm, http://ebible.org/web/ 